Wye, and after graduation he remained at the College for a year as a lecturer in agricultural chemistry, before going as head of the Advisory Department at Messrs. Fostock, Ltd., Welwyn Garden City. Later he became superintendent and technical adviser to Messrs. R. Silcock and Sons, Ltd., and from September 1945 was attached to the Animal Nutrition Institute, Cambridge. He was appointed to the staff of the Ministry of Agriculture and Fisheries in 1946, as a livestock husbandry advisory officer of the National Agricultural Advisory Service. He was lent to the Ministry of Food to take part in the recent Government food mission to Australia under the chairmanship of Sir Henry Turner.

Mr. D. S. Hendrie is thirty-nine years of age. He studied at the University of Glasgow and West of Scotland Agricultural College, and later at the School of Agriculture, Cambridge, and Ontario Agricultural College. During $1932-36$ he was an assistant lecturer and assistant farm manager to the West of Scotland Agricultural College, and in 1936 became district lecturer to the University of Leeds. In 1940 he was seconded to the Yorkshire (North Riding) War Agricultural Executive Committee as executive officer. He was appointed to the staff of the Ministry of Agriculture and Fisheries in 1946, being made county agricultural officer for the North Riding. \section{Central Committee for Adylt Education in H.M.
Forces}

MR. E. C. RFAp Anior lecturer in education, University College, full, has been appointed secretary to the Central Cofmittee for Adult Education in H.M. Fones the body representing the universities, local aufhities, and voluntary organisations which succeeds the Central Advisory Council. Dr. Basil A. Ve Council from its inception in January 1940 until its transformation last June into the Central Committee, will continue as acting secretary and deputy secretary respectively until Mr. Read takes office on April 1. Prof. Robert Peers, deputy vice-chancellor of the University of Nottingham and professor of adult education, is chairman of the Central Committee, succeeding Sir Walter Moberly, who was chairman of the Central Advisory Council.

A statement made in the House of Commons on December 17 by the Minister of Defence spoke of the great value attached by the Government to the co-operation of the civilian educational bodies with the Services during and since the War, and of the Government's satisfaction that this has now been put on a permanent basis. Fourteen universities and university colleges have consented to establish in their areas representative committees replacing the old ad hoc regional committees, and in the remaining areas the universities will continue, without special organisation for the purpose, to secure for the Services such assistance as may be requested. The universities have, of course, made it a condition that they shall not be directly responsible for the work of less than university extra-mural standard and that the ad. ministrative and educational cost shall be defrayed from Government sources. A large proportion of the work will be appropriate to local education authorities and voluntary bodies such as the Workers' Education Association and the Y.M.C.A., but this will all form part of the annual programme agreed upon with the Services in the area and co-ordinated and financed through the university committees.
Eels and their Environment

$3 \mid t$

IN 1937 Dr. G. D. Athanassopoulos, professor of zoology in the University of Thessaloniki (Greece), reported that elvers and very young eels kept for a few days, or extimes for only a few hours, in the tanks of ftspe culture stations in Italy, developed small bliptefs their head regions (Internat. Rev. Ges. Huflropiologie und Hydrographie, 36, 218; 1937). Lf fer he observed the same kind of blisters on elvers and very young eels in Greece. At first he believed this blistering to be caused by the water in the tanks becoming too warm, and attempted to prevent its occurrence by improving the flow of running water to the tanks in which the eels were kept. To his surprise, however, this treatment notably increased the incidence of blisters which, on examination, were found to contain atmospheric air. Further investi. gation revealed that the causative factor was exces. sive aeration of the water. The vesicles arise chiefly on the head, but occur also on other external surfaces of the body and even internally. They soon become centres of infection by bacteria and protozoa.

\section{Satellites of Uranus}

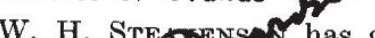
observations given the results of his (Mon. NAMROy. Ast. has arrivel at sot. Soc., 108, No. 2 ; 1948) and h/s 30 -inch reflector between January 9, 1947, and A pp 8,1948 , his observations of the position-angles of Umbriel, Titania and Oberon showed that there were no appreciable errors in their computed longitudes, so that the assumed periods of these three satellites are correct, or if there are discrepancies they must be very small. In the case of Ariel, the discrepancy between theory and observation of the hour-angle indicated that a correction of $+6 \cdot 1^{\circ}$ to the computed longitude was necessary. The epoch of Newcomb's orbit is $1872 \cdot 0$, from which it is deduced that the old period should be decreased by $0 \cdot 34$ sec. - a small error considering the shortness of the time between the discovery of the satellite and Newcomb's computation of its orbit. The period of Ariel, applying Steavenson's correction, is now $2 \cdot 5203796$ days. Revised magnitudes of the satellites are given, and the following magnitudes, which are not based on photometric measures but on Steavenson's familiarity with the North Polar Sequence and the fields of numerous variable stars, are closer to the truth than those usually given: Oberon, $13 \cdot 8$; Titania, 13.7 ; Umbriel, 14.5; Ariel, 13.7. The satellites are brighter than has been generally assumed by 0.2 , $0 \cdot 3,1 \cdot 5$ to $2 \cdot 5$, and $2 \cdot 7$ magnitudes, respectively. In the case of Titania and Oberon, Steevenson found decided changes in magnitude from night to night during his observations, and the variations seem to indicate that the axis of rotation of one or both of the satellites makes a large angle with the normal to the orbit-plane and may even lie in or at least close to that plane.

\section{India Society of Enpineers}

Is July the for first published in 1935, appeared under the new title Science ans. Elbineering; its content, which has always fonsisted almost exclusively of descriptive complent "on the Indian industrial outlook and erfits, romains unchanged. The altered name is intended to signify a break with the past and to symbolize the fact that India is now controlled by 
an independent administration. It is difficult to judge any Eastern publication by Western standards : the printing and lay-out of the present journal are certainly not good. Despite their shortcomings, however, these publications are valuable, for it is through such organs that Indian engineers are kept in touch with local progress in industrial practice and, when they enter the industrial field, with scientific developments as well.

\section{Post-doctorate Fellowships in Canada}

Some forty post-doctorate fellowships will be awarded by the National Research Council, Canada, in 1949-50 for research in pure chemistry and physics. The fellowships will be tenable in the National Research Council laboratories at Ottawa and in the labgratories of the Atomic Energy Project at Chalk B. ver, Ontario. There will be about twenty awards In chemistry, fifteen in physies and about six in atomic energy research. Fellowships are tenable for a period of one year but may be renewed for a second year upon application. The stipend is 2,820 dollars per annum and is free of income tax. A grant-in-aid of expenses will be made to persons from outside Canada, and a similar grant may be made on the termination of the fellowship. There are no restrictions as to the nationality of the applicant in the case of the Ottawa laboratories; but appointments at Chalk River are restricted to British subjects. Applications should be received at the National Research Council, Ottawa, not later than March 1, 1949, for this year's awards.

\section{Swedish Society for Clay Research}

A SwEDIsh Society for Clay Research was constituted at a/neeting at Hŏganäs, Sweden, on November 4, when representatives of geology, mineralogy, chemisty, soil science, ceramic industries, geotechnology, etc., were present. The Society will keep in gontact with the International Committee for Clay Sfadies (Comité International pour l'Étude des Argiles) formed in London last August. The following have been appointed members of committee of the new Swedish Society: Dr. G. Assarsson, of the Geological Survey, Stockholm (chairman); Dr. L. Silfverberg, of the Royal Swedish Geotechnical Institute, Stockholm (honorary secretary); E. Forslind (Swedish Cement and Concrete Research Institute, Stockholm); Dr. Rolf Norin (Höganäs), and Dr. Lambert Wiklander (Institute for Pedology, Ultuna, Uppsala).

\section{Sheffield Library: Technical Bibliographies}

THe Sheffield City Libraries have prepared fiftyfour bibliogray hies on a range of subjects in the fields of chemical/and industrial engineering, metallurgy, and physjal chemistry, with particular emphasis on the steo and metallurgical industries in Sheffield. Since/the number of copies is limited, the City Libarian states they can be sent only to research wbrkers or responsible works executives, and all inquiries should be addressed to him at the Adminis. tration Department, Central Library, Sheffield, 1.

\section{British Rheologists' Club}

Ax the annual general meeting of the British Rhegl6gists' Club, held at the Institute of Physics on October 29, 1948, the following officers were elected for the ensuing year : President, Prof. N. F. Mott ; Hon. Secretary, Dr. E. W. J. Mardles ; Hon. Treasurer, Dr. V. G. W. Harrison; Hon. Auditor,
Mr. A. de Waele. The following were also elected to the Committee : Dr. A. H. Nissan; Dr.J.G. Oldroyd ; Dr. G. W. Scott-Blair (editor); Mr. M. W. Thring; Mr. A. G. Ward (chairman); and (co-opted to represent the North of England) Mr. W. A. Richardson.

\section{Education for Family Life}

"Education for Family Life" is to be the theme of the planning forum which the British Social Hygiene Council is arranging on January 26, at 6.15 p.m. at the Planning Centre, 28 King Street, Covent Garden, W.C.2. This meeting is the second in a new series of forums which are to be held at formightly intervals during the period JanuaryMarch under the auspices of a group of voluntary societies engaged in social work. Mrs. Eva Hubback, principal of Morley College and chairman of the Education Committee of the London County Council, will be in the chair, and those taking part in the forum will be Dr. Letitia Fairfield, Dr. Ethel Dukes and Mr. Geoffrey Martin. Time will be allowed for discussion. Further information and tickets (price 18.) can be obtained at the door, or from the Planning Centre, 28 King Street, Covent Garden, London, W.C.2.

\section{University of London}

THE following appointments in the University of London have been announced :

Dr. C. B. Allsopp, to the University readership in physics tonable at Guy's Hospital Medical School; Dr. C. K. Simpson, to the part-time University readership in forensic medicine tenable at Guy's Hospital Medical School.

The following have been appointed readers in respect of the posts now held by them : Dr. W. E. Duncanson, University College (physics); Dr. D. B. Fry, University College (experimental phonetics) Dr. O. H. K. Spate, London School of Economics (geography); Dr. Andrew Wilson, University College and University College Hospital Medical School (applied pharmacology).

\section{Announcements}

The Federal Council of the Australian Institute of Agricultral Science has awarded its Medal for 1949 to prof. W. L. Waterhouse, of the University of Sydney. The award is made for the most outstanding service to Australian agriculture during the preceding ten years.

THE former Institute of Physical and Chemical Research, Womagome, Tokyo, has been dissolved and the work taken over by the Scientific Research Instifute, Ltd., at the same address. Its publications, the Scientific Papers and the Bulletin of the Institute, have been renamed the Journal and the Reports of the Scientific Research Institute.

VouUME 30 of the Transactions of the British Mycologipa Society is a jubileo volume which places on permanent record the papers presented at the conmemorative meeting in London during October $20-25,1946$. These deal with the Society's history, and with various facets of modern mycology; a full review of their contents appeared earlier in Nature (158, 693; November 16, 1946).

Erratum. In "Regenerated Keratin Fibres" by Dr. R. Wormell and Dr. F. Happey in Nature of Janyeryy 1, p. 18, in the legend to the figure, last line, for $D=3 \mathrm{~cm}$. read $D=4 \mathrm{~cm}$. 